Economic Diversity and Integration in a Pre-Colonial Indian Empire

Author(s): Kathleen D. Morrison and Carla M. Sinopoli

Source: World Archaeology, Vol. 23, No. 3, Archaeology of Empires (Feb., 1992), pp. 335-352

Published by: Taylor \& Francis, Ltd.

Stable URL: http://www.jstor.org/stable/124767

Accessed: 18/05/2011 12:10

Your use of the JSTOR archive indicates your acceptance of JSTOR's Terms and Conditions of Use, available at http://www.jstor.org/page/info/about/policies/terms.jsp. JSTOR's Terms and Conditions of Use provides, in part, that unless you have obtained prior permission, you may not download an entire issue of a journal or multiple copies of articles, and you may use content in the JSTOR archive only for your personal, non-commercial use.

Please contact the publisher regarding any further use of this work. Publisher contact information may be obtained at http://www.jstor.org/action/showPublisher?publisherCode=taylorfrancis.

Each copy of any part of a JSTOR transmission must contain the same copyright notice that appears on the screen or printed page of such transmission.

JSTOR is a not-for-profit service that helps scholars, researchers, and students discover, use, and build upon a wide range of content in a trusted digital archive. We use information technology and tools to increase productivity and facilitate new forms of scholarship. For more information about JSTOR, please contact support@jstor.org.

Taylor \& Francis, Ltd. is collaborating with JSTOR to digitize, preserve and extend access to World Archaeology. 


\title{
Economic diversity and integration in a pre-colonial Indian empire
}

\author{
Kathleen D. Morrison and Carla M. Sinopoli
}

\section{Introduction}

Empires are polities which, by definition, incorporate cultural and economic diversity. In the area of production, diversity is manifest in scale and organization, and in the nature and degree of integration of different productive spheres into an imperial order. In this paper, we examine productive systems and strategies in the Vijayanagara empire of southern India (c. AD 1340-1700), and discuss the ways in which they were shaped by their common participation in an imperial state. This empire, which dominated much of southern India for more than three centuries, included a range of linguistic, religious, occupational, and social groups from a variety of environmental zones. In this sense, it may be considered an empire (cf. Stein 1980: 393). The nature and degree of imperial élite involvement in, and control over, production varied greatly across time and space, but in general, economic integration was predominantly local in character and Vijayanagara emperors participated only indirectly in production and often received little or no material gain from it. In this paper, we argue that there was no single Vijayanagara economy. Instead, there existed a diversity of economic systems and strategies, which varied with the nature of the good being produced and its context of production: its political and military value; ecological and labor requirements; and role in regional and long-distance exchange networks.

By describing a range of productive spheres and focusing on their differential organization and integration into the imperial structure, we intend to highlight both the diversity of Vijayanagara agriculture and craft production, and the broad range of ways in which different social and occupational groups, ecological zones, and even polities were interconnected. There is no single imperial mode of integration, nor should the focus on integration and incorporation necessarily imply efficiency or even success in extraction and control on the part of the imperial élite. Rather, a multiplicity of forms and degrees of integration are apparent, only some of which provided gain to the center. The intervention of the Vijayanagara rulers in production was often indirect, effected through institutions such as the Hindu temple, or through intermediaries such as local élites or merchant groups. 


\section{The Vijayanagara empire: geographic extent}

At its maximal extent the Vijayanagara empire encompassed some 360,000 square kilometers and may have included as many as 25 million people (Stein 1989: 7, 44; Fig. 1). The territory claimed by the emperors included a range of topographic and environmental zones, from productive lowland coastal regions with seaports crucial to international trade (Subrahmanyam 1990: 26-7), to semi-arid interior uplands such as the region around the capital city.

The conceptual, though not geographic, center of the empire was its capital city, Vijayanagara, 'city of victory'. The walled core of the city encompassed an area of more than 25 square kilometers. Archaeological research at Vijayanagara (Fritz et al. 1985; Nagaraja Rao 1983; 1985; Michell 1990; Sinopoli 1991) has included surface documentation of architecture and domestic artifacts, and excavation in élite residential and administrative areas.

Beyond the walled city lies a fortified area more than 350 square kilometers in extent, which we have termed the 'greater metropolitan region' of Vijayanagara (Fig. 2); it includes numerous towns and villages, some of which were founded and patronized by the Vijayanagara kings, and it constitutes the immediate agricultural sustaining area of the city. Since 1988 we have been carrying out a program of systematic archaeological survey in this region in order to document the economic base of the city and the role of the Vijayanagara polity in regulating the production and distribution of agricultural and craft goods (Morrison and Sinopoli, forthcoming; Sinopoli and Morrison, forthcoming).

The core of the empire was an area of 30,000 square kilometers in the dry uplands surrounding the capital. Farmers and herders in some 1,200 villages in the region provided

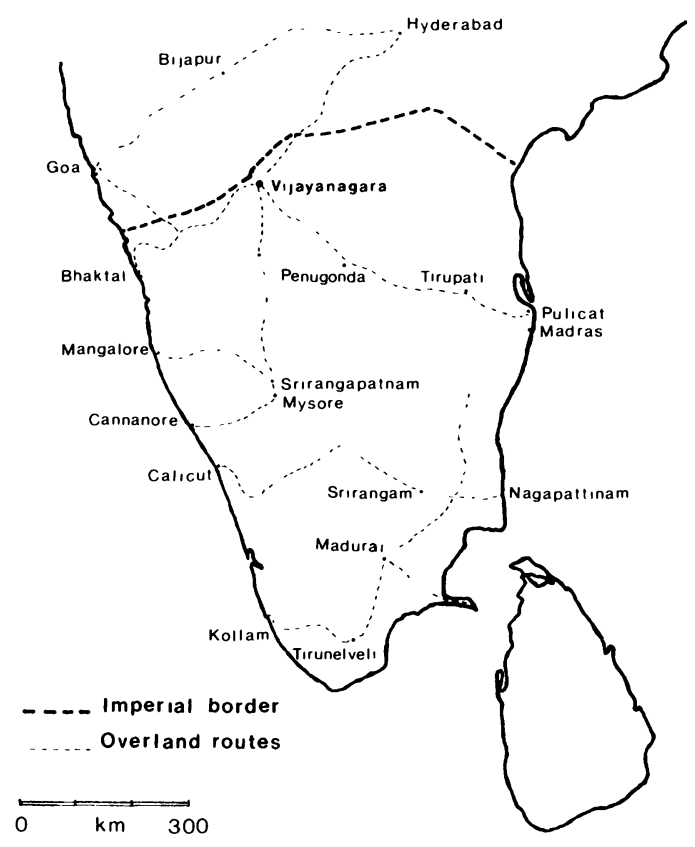

Figure $l$ The Vijayanagara cmpirc at c. AD 1500, showing major ports, urban centers, and overland trade routes. 

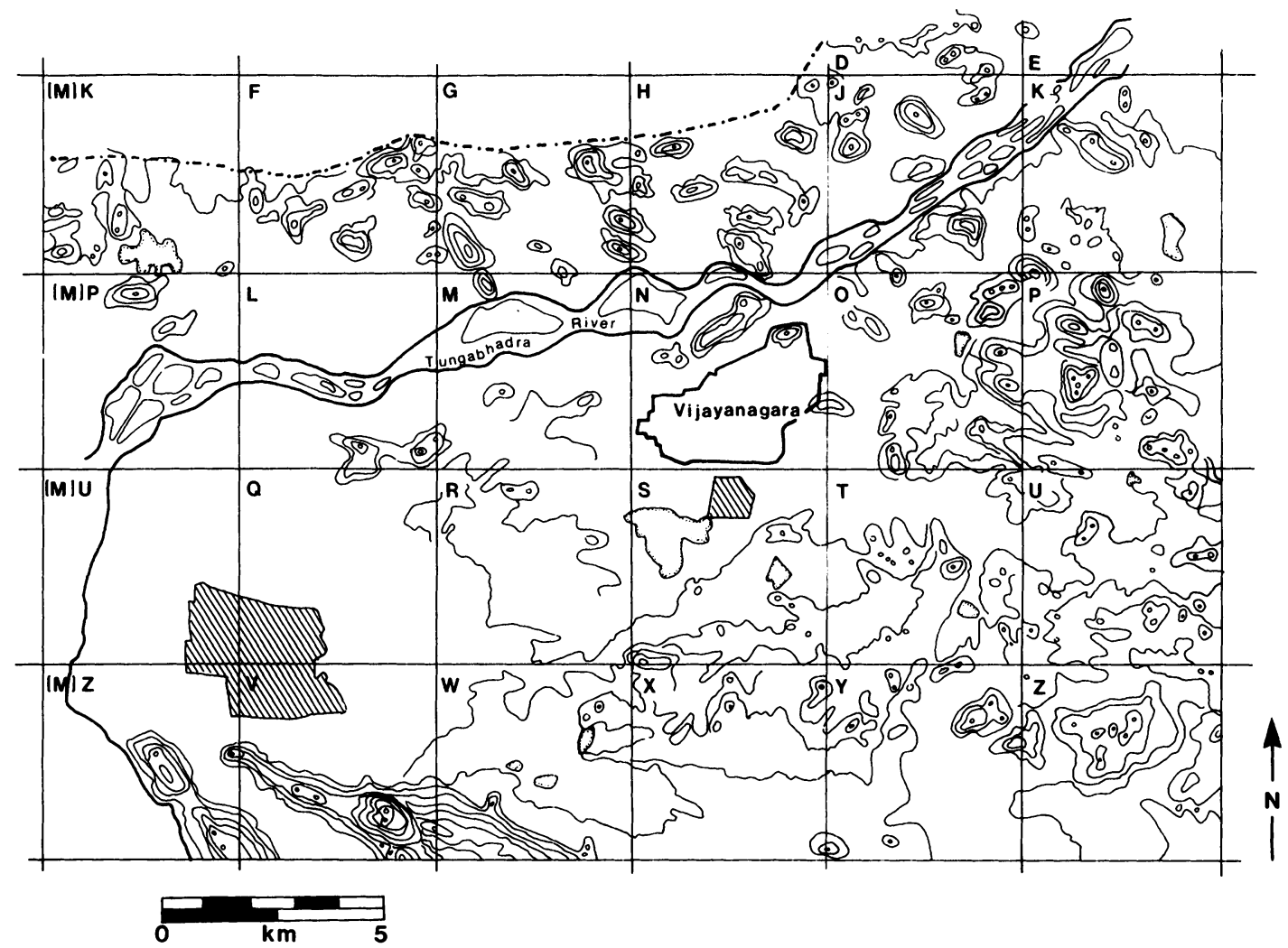

Figure 2 The greater metropolitan region of Vijayanagara. (Hatched lines indicate areas of modern settlement; dashed line, northern boundary of survey area.)

the productive basis for imperial revenues from this area, which Stein (1989:58) has argued provided the most secure and reliable resources and labor for royal exploitation. Beyond the imperial core lay the more distinct, and less well-integrated, portions of the empire. As discussed below, these areas were ruled in a variety of ways, through replacement and recruitment of local élites, military excursions, and, rarely, through state-run fortresses and outposts.

\section{Agricultural production}

Agricultural production was of primary importance in the Vijayanagara economy, not only for subsistence and urban provisioning, but also for supporting, albeit indirectly, imperial participation in international trade networks. The Vijayanagara empire maintained suzerainty over an extensive area, encompassing several ecological zones. These zones, discussed more fully below, supported a range of crops and cropping regimes, and were exploited by diverse ethnic and occupational groups. Agricultural production within each zone also varied in scale and organization. Forms of agricultural production in these different zones were integrated in different ways, depending on their products, locations, 


\section{Kathleen D. Morrison and Carla M. Sinopoli}

and scales. Three arenas of agricultural production are considered here, in order of increasing spatial scale: the Vijayanagara metropolitan region, the empire, and the Indian Ocean trade network centered on southern India. In each case, the links, or modes of integration between productive oppositions are considered, as is the role of imperial élites in directing or profiting from that production.

\section{The Vijayanagara metropolitan region}

In the area immediately surrounding the city of Vijayanagara, agricultural production was organized at a number of scales and at least three modes of integration can be discerned. The city of Vijayanagara is located in the semi-arid uplands of interior Karnataka, receiving a mean annual rainfall of about $500 \mathrm{~mm}$, most of which is concentrated in the months of June to September (Johnson 1969: 24, 32). Rainfall in this region exhibits a high degree of temporal and spatial variability, making rain-fed agriculture an uncertain enterprise. The city is located in a rocky landscape with limited arable land, except for the narrow alluvial strip along the Tungabhadra river.

In the Vijayanagara metropolitan region, 'wet' agriculture requires year-round irrigation, and was made possible primarily through the facility of river-fed canals. Other agricultural facilities which provided a constant supply of water were canal-fed reservoirs, or tanks. Crops grown under wet cultivation included rice, sugarcane, tree crops, and vegetables. Wet lands could be multicropped, or used to grow crops with long production cycles, such as sugarcane. The labor and scheduling implications of this form of production are significant: relatively large amounts of agricultural labor were required at peak times in the production cycle and, further, production demands were more continuous. In addition, the construction of the canals and reservoirs required to supply wet fields involved massive mobilizations of labor and a proliferation of occupational specialists such as engineers (Sewell 1984: 162), and even a specific caste of reservoir-diggers (Breckenridge 1985: 43). In the metropolitan region, wet agriculture was generally carried out on a larger scale than was 'dry' agriculture, but the range of variation in scale of wet facilities is significantly less than of dry facilities.

Much more common in the semi-arid Vijayanagara region was 'dry' agriculture, dependent either on a range of soil and water control and storage facilities, or on rainfall alone. These facilities included runoff-fed reservoirs, terraces, check-dams, wells, and gravel-mulched fields. Crops grown under dry cultivation included millets, sorghum, oilseeds, and cotton, dry fields rarely producing more than one crop per year. In general, production techniques in dry agriculture were less labor intensive than those of permanently cropped areas, and the scheduling of agricultural activities was also different. There exists little epigraphical or historical discussion of the organization of labor in constructing dry agricultural facilities, but, except for some of the large reservoirs, the labor input required would appear to have been relatively small. In the metropolitan region, dry agriculture was practiced on a variety of scales, from small, isolated plots, to immense interconnected systems of fields and facilities.

Several modes of integration link these diverse forms of agricultural production. One was economic, in that taxes and other obligations had to be met by producers. The Vijayanagara period was one of increasing monetization, and taxes on agriculturalists 
were collected both in cash and in kind (Palat 1987: 22). Breckenridge (1985: 51) suggests that payment of the landlord's share, or royal share (mèlväram), in kind was limited to rice, while inscriptions clearly indicate that the royal share on dry crops and garden produce was to be paid in cash. Contemporary travelers to the city (cf. Sewell 1984) describe large urban produce markets; production for these markets probably met the money requirements of most Vijayanagara-area agriculturalists.

A more direct, physical, form of integration between different groups of agriculturalists and scales of production is evident from archaeological data. This linkage is manifest in systems of connected facilities. For example, entire valleys were joined into a single watershed by reservoirs which collected runoff from the surrounding hills, watering fields below; the channels which watered the fields flowed downslope through a series of reservoirs, until the terrain no longer permitted such an arrangement (Morrison 1991). Little is known about the organization of production in such systems, which connected very small reservoirs watering only a few square meters to immense and formallyconstructed reservoirs watering tens of square kilometers. Modes of investment in large and small facilities were quite different; the mechanisms of control and the disposition of the produce may also have been.

These physical connections imply a need for cooperation in construction planning and in maintenance, as well as mechanisms for dispute resolution. The Vijayanagara rulers' direct involvement in agriculture concerned only substantial facilities such as canals and large reservoirs. As discussed below, this involvement was structured through the institution of the Hindu temple. However, even though imperial élites may have played no direct role in the construction and operation of small-scale facilities, the interconnection of features meant that changes in one part of the system had repercussions in others. For example, the extension of the canal system under royal patronage in the early sixteenth century made redundant several small reservoirs. Less dramatic, but equally important, would be the addition of a large reservoir, perhaps financed by royal investment, to a system of interlinked smaller reservoirs. Additional facilities could alter the flow of essential water and silt through the system.

The third mode of integration in Vijayanagara agriculture was the mechanism of temple investment (Pls 1-2). Temples in the Vijayanagara period were not only important ritual centers, but were also significant loci of agricultural investment and land control (Heitzman 1987: 792; Ludden 1985: 33; Stein 1982a: 113). These temples were often like small cities, supporting a cadre of ritual specialists, craft producers, and administrators.

Temple donations were usually in land or cash, and were made not only by kings and royal households, but also by local élites, temple employees, merchant guilds, and small investors. These gifts were not alienations (Breckenridge 1985:55), but investments, entitling the donor to material, as well as religious, benefits. Land was generally given with the express intent that it should be improved through the construction of irrigation facilities (Stein 1979: 194), and money gifts were often employed for the construction of reservoirs and other facilities. The person or institution responsible for constructing an irrigation facility was entitled to a share of the increase in production so created (kattu-kodaga rights; Stein 1980: 426-7). This share went to the temple, which offered the food to the deity. The produce or cooked food was returned as prasādam, sacred foodstuffs (Stein 1982a: 115). The donor's share of the increase was generally one-quarter. 


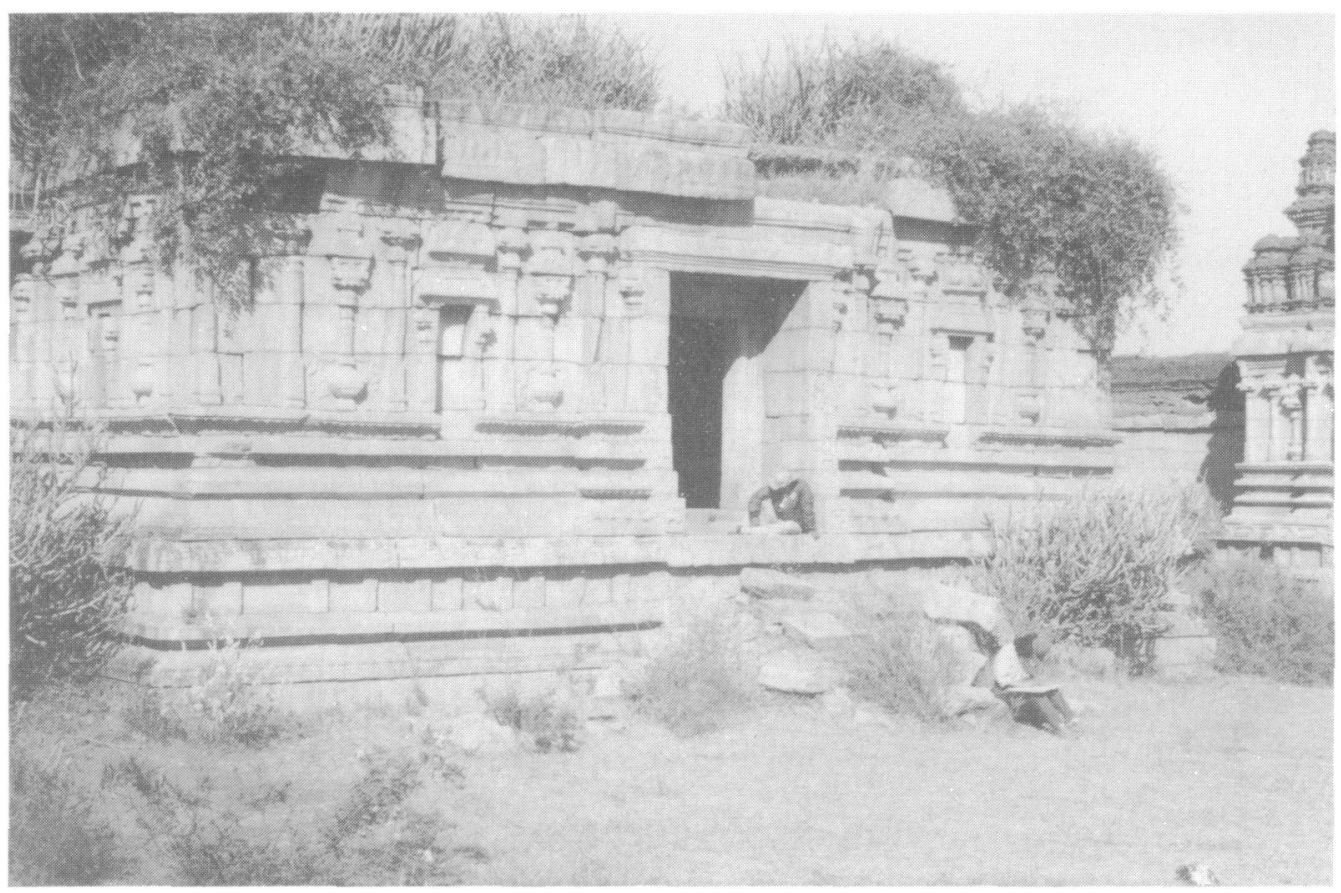

Plate 1 Site VMS-142, late Vijayanagara period temple complex, main shrine.

This share was received as prasädam, which could be consumed or sold. In this way, the donor was able to create resource entitlements, often from several distant areas (Breckenridge 1985: 63).

When both archaeological and historical data are considered, it becomes clear that there is a greater range of variation in agricultural facilities than is accounted for in the inscriptional record of temple donations. In many cases, the donation and construction record of larger reservoirs can be matched with the physical remains of that reservoir, but such correspondences can not be made for the very small agricultural features. Thus, it seems clear that the mode of investment for these very small facilities differed from that of the larger ones. It may be the case that very small facilities were constructed and maintained by individual households or village groups without the assistance of temples. As discussed above, however, the interdependent nature of agricultural features, especially with respect to water and soil, made it impossible for small cultivators to be entirely disengaged from the activities of kings and temples, even if they should wish to do so.

Within the metropolitan region, canals and several of the larger reservoirs were financed by the Vijayanagara rulers through temple investments. The material benefit to Vijayanagara kings from these large-scale investments would have been significant. The areas watered by canals and large reservoirs were extremely productive, and the donor's share would have been sizeable. However, it is important to note that in this respect Vijayanagara rulers were behaving in a manner similar to that of other local rulers who 


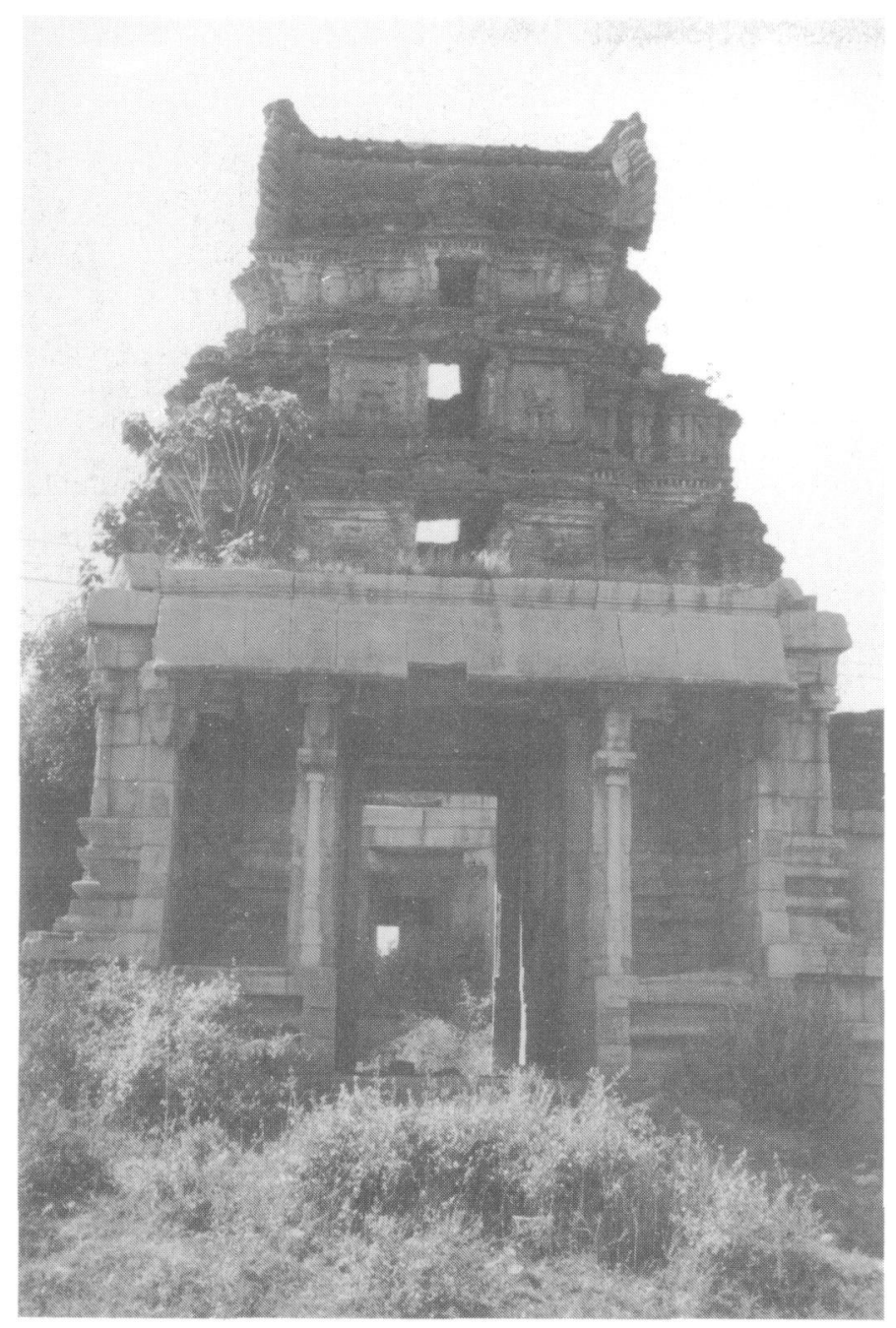

Plate 2 Site VMS-142, late Vijayanagara period temple complex, east gateway.

invested in agriculture in their home districts. In a material sense, the difference may have been simply in the scale and spatial range of their investments.

\section{The Vijayanagara empire}

The Vijayanagara empire encompassed several distinct topographic and ecological zones (Fig. 3). These zones included the dry, upland regions of the interior; mountainous, forested areas; and well-watered coastal areas. The Vijayanagara period saw an expansion of cultivation in the dry zones (Breckenridge 1985: 42; Palat 1987: 15-18) and an increase in their political importance.

The coastal regions of south India were important for several reasons. These areas, along the Kanara, Malabar, and Coromandel coasts, receive a higher, more predictable, and more equitably distributed rainfall than do the inland areas (Fig. 4). Equally 


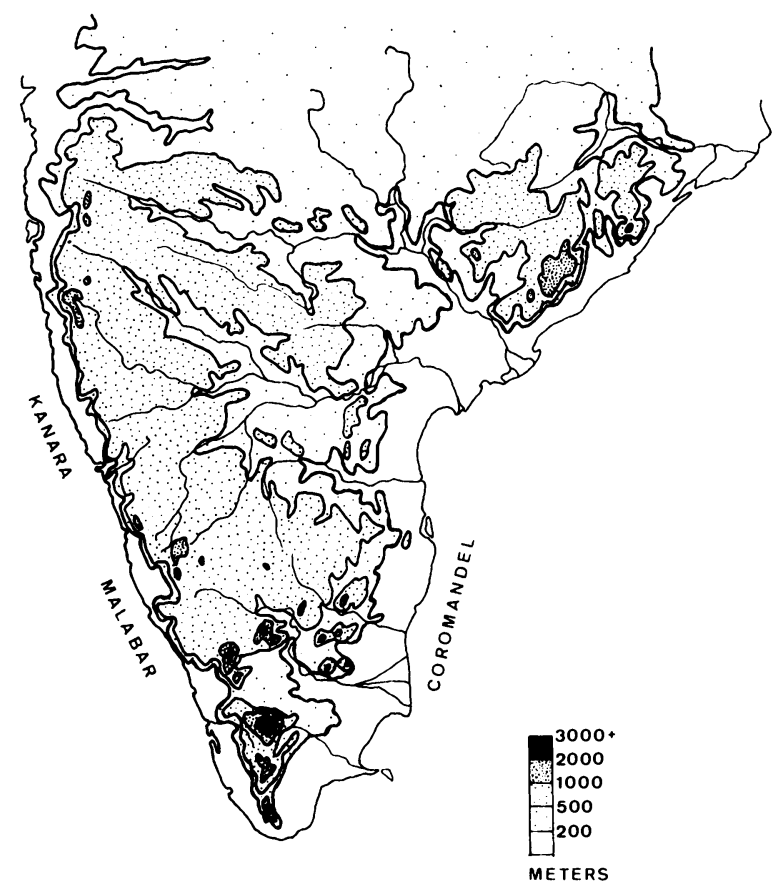

Figure 3 Topographic zones of southern India.

important to lowland agricultural regimes were the large rivers and rich alluvial deltas, which supported an intensive irrigated agriculture based on river-fed canals and canal-fed reservoirs.

Integration between different agricultural zones in the empire was accomplished in a number of ways. One of the most important of these was temple investment. Large temple centers maintained lands and invested in irrigation facilities across a wide area. Through gifts to temples, investors could maintain access to resources from a diversity of environmental zones, and could create and affirm interregional social and political ties.

The nature of political control exercised by the Vijayanagara rulers in these distant areas is clearly important for understanding the nature and degree of success of imperial revenue extraction. The Vijayanagara empire never directly controlled areas along the Malabar coast, although they did demand and receive tribute from several small polities on the Kanara coast. The conquest of the Coromandel coast and the far south was among the important accomplishments of Vijayanagara rulers in the fourteenth century. Thus, except for the Malabar coast, the Vijayanagara empire claimed hegemony over all of these wealthy, surplus-producing regions. From about the tenth century AD up to the Vijayanagara period, agricultural decision-making was carried out at a local level, centered around individual irrigation networks (Ludden 1985: 34-5; Sastri 1958: 158--9; Stein 1980: 417, 1982b: 35), and local élites maintained control over the coastal zones even under a succession of state systems. By the sixteenth century, however, non-local military chiefs or nāyakas, installed by the Vijayanagara rulers, supplanted indigenous élites. Local irrigation control and self-government were also subverted, replaced by temple involvement in agricultural production (Appadurai 1978: 49; Heitzman 1987: 808, 812; 


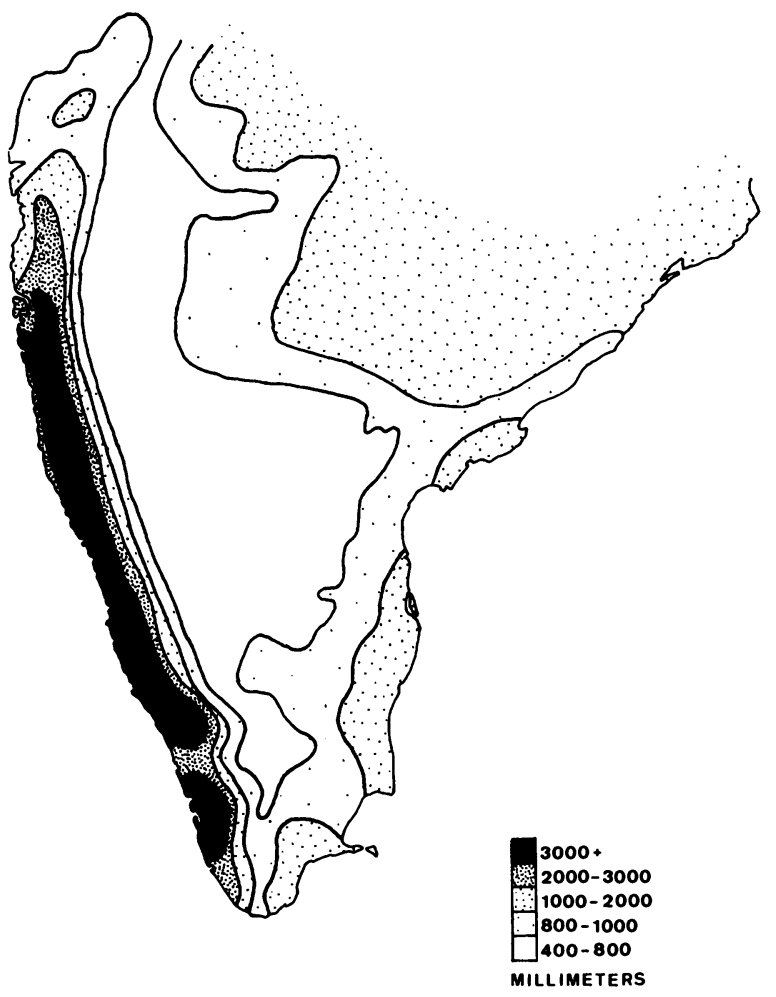

Figure 4 Rainfall zones of southern India.

Stein 1982b: 37). Nāyaka rule represented a significant centralizing attempt on the part of the Vijayanagara rulers, but the nāyakas were able to forge local ties through investment and alliance with religious centers and temples (Appadurai 1978), and proved increasingly difficult for the Vijayanagara emperors to control. Thus, although pre-existing indigenous élites and institutions for the local control of agriculture were supplanted during the Vijayanagara period, direct imperial control over production could not be effectively implemented or maintained.

The degree to which the Vijayanagara emperors were able to benefit from the rich agricultural produce of the coastal zones has been subject to a considerable amount of debate (Palat 1987; Stein 1989). Tax collections were not carried out by functionaries of the imperial government, but instead were 'farmed' to private entrepreneurs. Such collections were made under the aegis of local rulers, who were in turn subject to revenue demands by the center. Temple investment allowed the forging of social, political, and material ties between different ecological zones in the empire. The principal beneficiaries of that integration appear to have been local élites, who were among the most important donors, even while acknowledging the hegemony of Vijayanagara in the record of their donations.

The Vijayanagara rulers were able to extract agricultural surplus and cash from the conquered wet zones in at least three ways. The first was through tribute demands on local leaders, whose resources ultimately derived from agricultural production. Where nāyakas loyal to the Vijayanagara rulers were in control, the success of such revenue demands was 
relatively greater (Stein 1989). The second method was direct, through military raids and plunder. The third was through temple investment, a strategy not, however, limited to the imperial élite: Vijayanagara rulers were important temple patrons, and were able to alter local political structure, but they did not or could not directly control agricultural production in the wet zones.

\section{Rice, spices, and the Indian Ocean trade}

During the Vijayanagara period, southern India was involved in an extensive trade network stretching from China to the Mediterranean (Chaudhuri 1985; Digby 1982). Vijayanagara involvement in this long-distance exchange was the least direct and most incidental to imperial strategies of any arena of agricultural production discussed thus far. The Vijayanagara rulers indirectly profited from, rather than participated in, the international trade. Among the important commodities in this trade were agricultural products, such as pepper (Piper nigrum), indigenous to the tropical forests of the Malabar coast (Purseglove et al. 1981: 10). Although many early European visitors to the region (cf. Foster 1968: 46) believed that pepper required no effort to grow, in fact it demanded specialized conditions for production and processing.

The involvement of the Portuguese in the spice trade (Boxer 1969; Mathew 1983) in the early sixteenth century AD created an explosion of demand that could only have been met by increasing the area under pepper production. In part, the production of pepper and the growing and gathering of other forest products involved in the Indian Ocean trade were carried out by ethnically distinct 'hill people' who made a living by hunting, gathering of forest products, swidden cultivation, and trading with lowland agriculturalists (Fox 1969). There is evidence for the antiquity of this trading relationship (Hockings 1985: 226, 228; Morris 1982: 23), and consequent dependence of hill peoples on imported grains and other items of basic subsistence. The other participants in this trade, from the middlemen brokers to the residents and rulers of the coastal trading emporia of the Malabar coast, were also dependent upon imported grain (Mathew 1983: 20). The increasing scale of spice production and the concomitant land, labor, and scheduling constraints would have reduced the ability of the spice areas to provide for their own subsistence; in large part, this need was met by imports of rice from Vijayanagara-controlled areas on the Kanara and Coromandel coasts (Subrahmanyam 1984: 442).

Vijayanagara rulers had always been interested in controlling west coast ports, particularly in order to monopolize the trade in militarily essential war-horses and artillery (Pearson 1981: 70), yet, these two commodities apart, their control of trade was never direct, even in the areas which were nominally under imperial control. The Vijayanagara kings were, however, involved in the complex interconnection between producers, consumers, merchants, and rulers in the trading network. The increasing demand for rice must have prompted intensification of rice production in the exporting areas of the Kanara coast, an increase which should have been mirrored in the landlord's share of produce in this region and, ultimately, in enhanced royal revenues. Like other parts of the empire outside the core, the collection of land revenue was carried out locally (Subrahmanyam 1984: 440), and imperial extraction of surplus was made in the form of tribute demands. 
Subrahmanyam (1984: 440-1) notes that the imperial authorities concerned themselves directly with only two taxes: port customs, and tolls on the highway leading to the city of Vijayanagara. In a real sense, the integration of different forms of agricultural production along the west coast was local in character, and the imperial benefit derived from it did not fundamentally alter its structure. The Vijayanagara rulers neither controlled nor directed the production of spices, or of the rice that fueled the trade and the traders, but instead set themselves up above the relationships of production to extract a nominal surplus from the system.

\section{Craft production}

Information on craft production during the Vijayanagara period varies considerably in nature and extent: some crafts are mentioned frequently in Vijayanagara tax records and legal texts, while references to others are scarce. The differential appearance of specific crafts in the historical record seems to be directly correlated with the political and economic significance of the products and their producers. In this section, three different arenas of craft production are examined: textile manufacture, iron working, and ceramic production.

\section{Textiles}

There are numerous historical references to weavers and their products. Cotton and silk textiles and thread were important commodities in international trade, and finely-made cloths for élite garments were in high demand at the capital and in the emergent urban centers throughout the empire. Textiles were produced in a variety of productive contexts throughout southern India, ranging from individual households to workshops of up to 100 looms run by masterweaver/merchants (Ramaswamy 1985b). A number of major Vijayanagara-period centers of textile production, located along the Coromandel coast and in other zones of good cotton soils (Ramaswamy 1985c: 6), consisted of clusters of weaving villages, or were associated with temple complexes in urban settings (idem 1985b: 302-4). Textiles were woven by members of localized castes or groups of Muslim weavers (idem 1985c: 14), each of whom produced distinct styles of cloth; other specialized occupational groups associated with textile production were cotton cleaners, carders, spinners, dye makers, and merchants (idem 1985b: 309).

Textile production and trade provided important sources of revenue for Vijayanagara rulers. Kings did not, however, seek to directly manage production in imperial workshops. Rather, revenue was derived from taxes levied on weaving communities: on looms, thread, and the sale of cloth (idem 1985c: 86). The output of Vijayanagara weavers was massive. Ramaswamy has estimated that merchants at the major eastern port of Pulicat shipped some 4.5 million meters of cloth per year to Southeast Asia (1985c: 76). Several other comparable ports existed on the east and west coasts and, as noted above, internal trade was also important. Even with local leaders and tax farmers siphoning off a significant portion of the tax revenue, the Vijayanagara emperors received substantial income from the textile trade. 


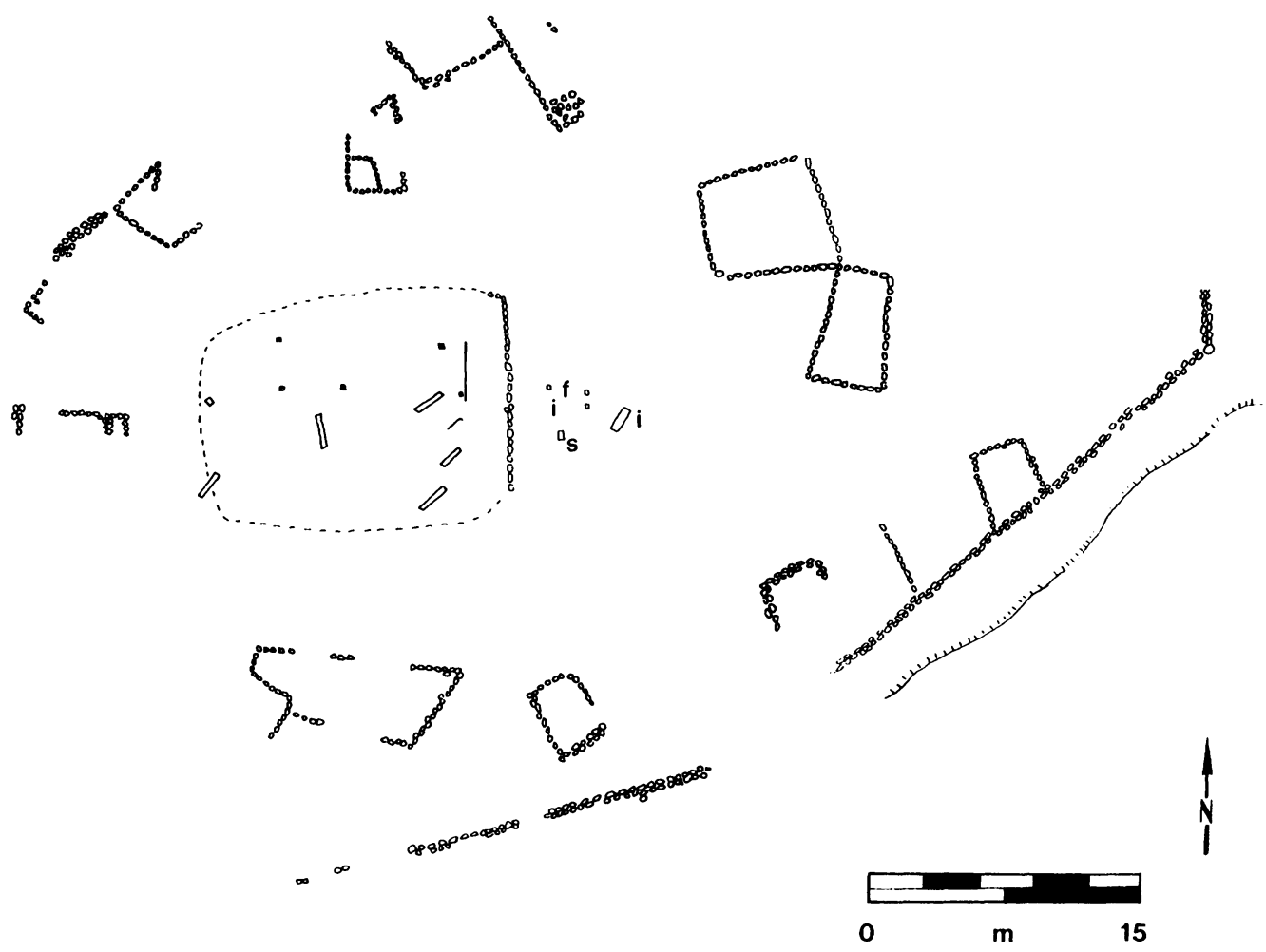

Figure 5 Site VMS-111, weaver's temple ( $\mathrm{i}=$ inscription; $\mathrm{f}$ and $\mathrm{s}=$ sculptural elements).

Although the weavers of cloth for commoners' garments did not see substantial increases in their wealth or status during Vijayanagara times, other communities and individual weavers clearly did. The importance of textile production to Vijayanagara's rulers is evident in the honors accorded by them to some weaving communities. These included: (1) economic privileges, such as gifts of land, or remissions or reductions in taxes (often following effective tax protests or mass migrations); (2) social privileges, such as the right to live in two-storey houses or blow the conch shell on important occasions; and (3) ritual privileges, including rights to participate in temple worship and dispute resolution (Ramaswamy 1985c: 103-7).

The improved status of individual weavers and weaving communities is evident in inscriptions recording donations by individuals and groups to temples. We have located a small shrine complex in the Vijayanagara metropolitan region with a sixteenth-century inscription recording that it was built by Nagayya, son of a weaver, in honor of his guru. This complex, located along a major road just outside of the city (Fig. 5), provides powerful testimony to the position of an individual weaver in the late Vijayanagara period.

\section{Iron goods}

Vijayanagara iron products included a broad range of goods, ranging from utilitarian items, such as agricultural tools, to weapons. Iron workers included miners, smelters, and 
smiths. Mining of iron ore was carried out on a large scale in interior Andhra Pradesh and in the region of Mysore (Subrahmanyam 1990:30), and near the capital in the iron-rich Sandur Hills (Ramaswamy 1985b: 425). The volume of Vijayanagara-period iron production was considerable, and iron finished goods and ingots were exported from south India to southwest Asia (Abraham 1988: 170-1; Digby 1982: 144). We have no evidence for government-run mines or iron workshops and we know little about how the iron trade was organized. There is, however, evidence that Vijayanagara rulers acknowledged the importance of at least certain communities of metal workers. Blacksmiths were granted benefits similar to those of weavers, including tax remissions, certain material prerogatives, and temple privileges.

Iron artifacts recovered at Vijayanagara are often badly corroded and difficult to identify. Swords or daggers have been recovered in excavations in élite palace areas. Four spatially dispersed iron-working sites have thus far been identified in the Vijayanagara metropolitan region; all are small, and three consist only of surface scatters of iron, slag, and over-fired red brick. The fourth (VMS-121, Fig. 6) contains a small rectangular furnace containing vitrified crucible fragments. A light scatter of slag and iron fragments extends over several thousand square meters in the fields surrounding this structure. Slag was also incorporated into the platform fill of a nearby late Vijayanagara temple. This evidence suggests that iron working in the metropolitan region was relatively small in scale. Significant quantities of finished implements must have been transported to the capital from more distant centers of production.

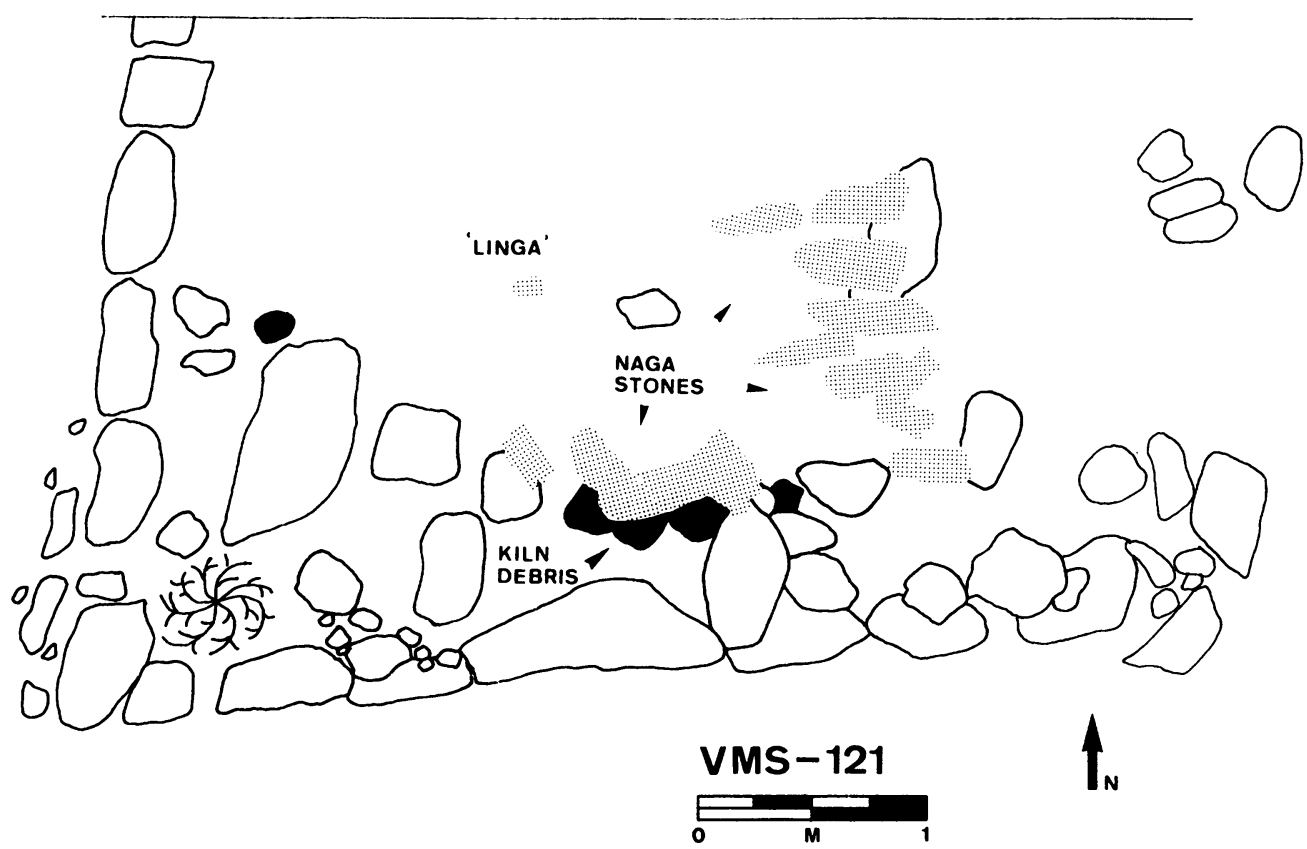

Figure 6 Site VMS-121, iron working site. Black areas indicate kiln debris. The site was later converted to a naga, or cobra, shrine. Nagas indicated by shaded areas. 


\section{Ceramics}

Potters and their products are seldom mentioned in Vijayanagara texts. Ceramics were essential goods used by all members of Vijayanagara society, but they were low-value items, important neither in exchange nor as status markers. Some potters were village or temple servants who were remunerated in cash, grain or access to tax-free lands (Nagaswamy 1965: 368; Ramaswamy 1985a: 95). Many Vijayanagara potters must have sold their products in daily or periodic markets or to middlemen merchants. The status of members of the potting caste remained low throughout the Vijayanagara period, and there is no evidence that they received privileges comparable to those accorded to weavers and smiths.

In contrast to the historical record, archaeological evidence provides ample testimony to the ambiguity of ceramics. Earthenware fragments litter the surface of the capital, and excavations in the royal administrative and residential zones of the capital have yielded thousands of sherds and complete vessels (Sinopoli 1991; Tripathi 1987). Ceramic workshops have not yet been identified at the capital or in the metropolitan region. This in itself suggests that production was relatively small in scale and spatially dispersed. Vessel morphology and dimension are extremely variable, and there seems to have been little emphasis on standardization in ceramic forms, again suggesting production in small-scale, localized workshops (Sinopoli 1988).

\section{Discussion}

The diverse arenas of production in the Vijayanagara empirc present very different pictures in terms of imperial élite involvement and benefit. The Vijayanagara metropolitan region supported the capital city with forms of agriculture ranging from small rain-fed plots to large areas of perennially irrigated land. Kings and others invested in agricultural facilities in the area, facilities often physically linked into complex systems of soil and water control. Revenue demands on local farmers, herders, craft producers, and merchants were probably met by participation in the urban markets.

Outside the upland core of the empire, coastal areas of highly productive agriculture were integrated politically and economically with the dry interior through temple investments. The role of temples as agricultural entrepreneurs created a nexus in which imperial élites, regional leaders, merchants, and other investors were bound together into a common enterprise. Vijayanagara rulers replaced local élites with non-indigenous nāyakas, or recruited élites into the imperial polity, but otherwise worked within the structure of temple agriculture. Nāyaka participation in temple investment changed the scale of agricultural integration from a local to a regional one (Stein 1979: 193), and provided the institutional means for these leaders to forge local economic and power relations independent from the center (Appadurai 1978).

The tropical forests and fertile west coast of India provided the ecological backdrop for a symbiotic relationship between rice and spice production that fueled an international trade. Except for a few military commodities, the Vijayanagara rulers remained disengaged from the operation of that trade, content simply to extract tolls and taxes. 
Weavers, iron-workers, and potters all produced goods essential to the Vijayanagara economy. However, the importance of these goods, as revenue generators, status items, and political objects varied tremendously. Weavers and smiths produced goods of value for élite consumption and international trade. Taxes on these producers were high, but craft communities were also accorded important economic and ritual privileges. For the most part, the relation between rulers and producers of valued craft goods was not one of coercion or direct control, but significant interest and involvement on the part of imperial élites is indicated. Pottery manufacture during the Vijayanagara period, on the other hand, appears to have occurred on a small scale, independent of imperial involvement or concern. Potters produced goods that were essential to daily life, but provided neither status nor significant revenue. Unlike weavers or smiths, whose activities were dramatically affected by political conditions such as the security of trade routes or demands for weaponry, potters produced goods which had a stable demand and local distribution, but were not particularly important in power relations.

It is not possible to isolate a single imperial economy or resource strategy: rather, a unitary political and ritual hegemony was economically splintered, organized primarily on a regional level and integrated by non-imperial institutions such as temples and traders. However, even though élite involvement in production was often indirect, producers were not unaffected by their participation in an imperial polity. Because of the integration of different productive spheres, the activities of emperors often had repercussions for producers not directly involved in royal enterprises.

\section{Acknowledgements}

We would like to thank the Government of India, the Archaeological Survey of India, the American Institute of Indian Studies, and the Directorate of Archaeology and Museums, Karnataka, for their assistance in carrying out fieldwork in India. Support for the Vijayanagara survey was granted by the National Geographic Society, the Wenner-Gren Foundation, and the American Institute of Indian Studies.

26.vii.91

K. D. Morrison

Department of Anthropology

University of California

Berkeley, California

94720 USA

C. M. Sinopoli

Department of Anthropology

University of Wisconsin

Milwaukee, Wisconsin

53201 USA 


\section{References}

Abraham, M. 1988. Two Medieval Merchant Guilds of South India. New Delhi: Manohar.

Appadurai, A. 1978. Kings, sects, and temples in south India, 1350-1700 AD. In South Indian Temples: An Analytical Reconsideration (ed. B. Stein). New Delhi: Vikas, pp. 47-74.

Boxer, C. R. 1969. The Portuguese Seaborne Empire 1415-1825. New York: Knopf.

Breckenridge, C. A. 1985. Social storage and the extension of agriculture in south India 1350 to 1750. In Vijayanagara - City and Empire (ed. A. L. Dallapiccola). Wiesbaden: Franz Steiner Verlag, pp. 41-72.

Chaudhuri, K. N. 1985. Trade and Civilisation in the Indian Ocean: An Economic History from the Rise of Islam to 1750. Cambridge: Cambridge University Press.

Digby, S. 1982. The maritime trade of India. In The Cambridge Economic History of India, Vol. I: c. 1200-c. 1750 (ed. T. Rayachaudhuri and I. Habib). Cambridge: Cambridge University Press, pp. 125-62.

Foster, W. ed. 1968. Early Travels in India 1583-1619. New Delhi: S. Chand and Co.

Fox, R. G. 1969. Professional primitives: hunters and gatherers of nuclear South Asia. Man in India, 49(2): 139-60.

Fritz, J. M., Michell, G. A. and Nagaraja Rao, M. S. 1985. Where Kings and Gods Meet: The Royal Centre at Vijayanagara. Tucson: University of Arizona Press.

Heitzman, J. 1987. Temple urbanism in medieval south India. Journal of Asian Studies, 46(4): 791-826.

Hockings, P. 1985. Advances in the social history of the peninsular tribes. In Studies in South India (eds R. E. Frykenberg and P. Kolenda). New Delhi: New Era Publications, pp. 217-37.

Johnson, B. L. C. 1969. South Asia. London: Heineman.

Ludden, D. 1985. Peasant History in South India. Princeton: Princeton University Press.

Mathew, K. S. 1983. Portuguese Trade with India in the Sixteenth Century. New Delhi: Manohar.

Michell, G. A. 1990. Architectural Inventory of Vijayanagara, 2 vols. Mysore: Directorate of Archaeology and Museums.

Morris, B. 1982. Hill Traders: A Socioeconomic Study of the Hill Pandaram. New Jersey: The Athalone Press.

Morrison, K. D. 1991. Supplying the city: the role of reservoir irrigation in an Indian urban landscape. Paper presented at the 56th Annual Meeting of the Society for American Archeology, New Orleans, April 24-9.

Morrison, K. D. and Sinopoli, C. M. Forthcoming. Archaeological survey in the Vijayanagara metropolitan region: 1990. In Vijayanagara: Progress of Research 1990-91 (ed. D. V. Devaraj). Mysore: Directorate of Archaeology and Museums.

Nagaraja Rao, M. S. (ed.) 1983. Vijayanagara: Progress of Research 1979-83. Mysore Directorate of Archaeology and Museums.

Nagaraja Rao, M. S. (ed.) 1985. Vijayanagara: Progress of Research 1983-84. Mysore: Directorate of Archaeology and Museums.

Nagaswamy, R. 1965. South Indian temples as an employer. Indian Economic and Social History Review, 2: 367-72.

Palat, R. 1987. The Vijayanagara empire: re-integration of the agrarian order of medieval South India. In Early State Dynamics (eds H. J. M. Claessen and P. van der Velde). Leiden: E. J. Brill, pp. 170-86. 
Pearson, M. N. 1981. Coastal Western India: Studies from the Portuguese Records. XCHR Studies Series 2. New Delhi: Concept Publishing.

Purseglove, J. W., Brown, E. G., Green, C. L. and Robbins, S. R. J. 1981. Spices, Vol. I. London and New York: Longman.

Ramaswamy, V. 1985a. Artisans in Vijayanagar Society. Indian Economic and Social History Review, 22: 417-44.

Ramaswamy, V. 1985b. The genesis and historical role of the masterweavers in south Indian textile production. Journal of the Economic and Social History of the Orient, 28: 294-325.

Ramaswamy, V. 1985c. Textiles and Weavers in Medieval South India. New Delhi: Oxford University Press.

Sastri, N. 1958. A History of South India. London: Oxford University Press.

Sewell, R. 1984. A Forgotten Empire (Vijayanagar): A Contribution to the History of India. New Delhi: Asian Educational Services reprint.

Sinopoli, C. M. 1988. The organization of craft production at Vijayanagara, South India. American Anthropologist, 90: 580-97.

Sinopoli, C, M. 1991. Pots and Palaces: Archaeological Ceramics from the Noblemen's Quarter of Vijayanagara. New Delhi: Manohar and the American Institute of Indian Studies.

Sinopoli, C. M. and Morrison, K. D. Forthcoming. The Vijayanagara metropolitan survey: The 1988 season. In Vijayanagara: Progress of Research, 1988-90 (ed. A. Sundara). Mysore: Directorate of Archaeology and Museums.

Stein, B. 1979. Integration of the agrarian system of south India. In Land Control and Social Structure in Indian History (ed. R. E. Frykenberg). New Delhi: Manohar, pp. 175-216.

Stein, B. 1980. Peasant State and Society in Medieval South India. New Delhi: Oxford University Press.

Stein, B. 1982a. Vijayanagara. In The Cambridge Economic History of India, Vol. I: c. 1200 to c. 1750 (eds T. Rayachaudhuri and I. Habib). Cambridge: Cambridge University Press, pp. 102-24.

Stein, B. 1982b. South India: some general considerations of the region and its early history. In The Cambridge Economic History of India, Vol. I: c. 1200 to c. 1750 (eds T. Rayachaudhuri and I. Habib). Cambridge: Cambridge University Press, pp. 14-42.

Stein, B. 1989. Vijayanagara. The New Cambridge History of India I.2. Cambridge: Cambridge University Press.

Subrahmanyam, S. 1984. The Portuguese, the port of Basrur, and the rice trade, 1600-50. Indian Economic and Social History Review, 21: 433-62.

Subrahmanyam, S. 1990. The Political Economy of Commerce: Southern India, 1500-1650. Cambridge: Cambridge University Press.

Tripathi, R. C. (ed.) 1987. Indian Archaeology 1984-85 - A Review. New Delhi: Archaeological Survey of India.

\section{Abstract}

Morrison, Kathleen D. and Sinopoli, Carla M.

\section{Economic diversity and integration in a pre-colonial Indian Empire}

Empires contain a multiplicity of productive systems and strategies which may be differentially integrated with each other and the center. This paper examines six aspects of agricultural and craft 


\section{Kathleen D. Morrison and Carla M. Sinopoli}

production in the south Indian empire of Vijayanagara (c. AD 1340-1700). Agricultural production in the diverse ecological zones of the empire was integrated primarily through Hindu temples, and trade and craft production through temples and taxation. The economic value and political role of the goods produced, as well as the location of the producers, were the principal factors in determining the nature and degree of imperial involvement in production. 